\title{
How Green Marketing Can Create a Sustainable Competitive Advantage for a Business
}

\author{
Dinuk Arseculeratne ${ }^{1} \&$ Rashad Yazdanifard ${ }^{1}$ \\ ${ }^{1}$ Center of Southern New Hampshire University (SNHU) Programs HELP College of Arts and Technology, \\ Malaysia \\ Correspondence: Dinuk Arseculeratne, Center of Southern New Hampshire University (SNHU) Programs HELP \\ College of Arts and Technology Kuala Lumpur, Malaysia. E-mail: dinuk.arseculeratne@gmail.com
}

Received: October 28, 2013

Accepted: November 22, 2013

Online Published: December 23, 2013

doi: $10.5539 /$ ibr.v7n1p130

URL: http://dx.doi.org/10.5539/ibr.v7n1p130

\begin{abstract}
The concept of green marketing has undergone tremendous transformation as a business strategy since its first appearance in the 1980's. Business firms have realized the importance of green marketing as a means of gaining competitive advantage over rivals in the industry. Business strategy of a business is devised in response to the changing needs in the market and Green marketing has received a tremendous boost with the revival of environmental consciousness among consumers. Green marketing in fact represents a paradigm shift strategy in many business firms since it has altered the manner in which a business goes about in reaching out to the customers.

The thesis paper discusses the importance of competitive advantage for a business firms and how green marketing is being relied upon by business firms to realize competitive advantage. The term green marketing and its main characteristics are described in order to understand the import of it in the present business world context. The thesis paper dwells at length on green market strategy implementation so as to provide glimpse as to how various businesses deploy marketing mix in green marketing. The necessary prerequisites for a successful green marketing strategy are identified and the drawbacks encountered by a business firm embarking on green marketing strategy are analyzed while evaluating some strategies in place. The success of green marketing strategy, as the thesis paper underlies, rests largely on the contribution, interaction and cooperation between different stakeholders of a business.
\end{abstract}

Keywords: green marketing, competitive advantage, sustainability

\section{Introduction}

Competitive advantage of a business refers to a firm's ability to earn consistent profits over rival firms in the industry by delivering a service which cannot be matched easily. Much of a firm's competitive advantage is discussed by Michael Porter in his work on competitive advantage and the forces of competition. Porter has identified commitment to a generic strategy such as cost, differentiation or focus as a means of gaining competitive advantage (Porter et al., 1995).

The strategy of low cost involves providing a product at relatively a cheap price by reducing a firm's cost. The strategy of differentiation entails providing a unique product which can be clearly distinguished from the existing products in the market. The focus strategy is aimed at targeting a select group of customers whose needs are being exclusively catered to. The focus strategy may contain both cost element and differentiation aspect. The type of strategy to be used in the business world has aroused much interest and it can be surmised the strategy too is responsive towards the consumer needs (Porter et al., 1995).

A cost strategy would require operational excellence through cost reduction, better handling of sources of finance and new modes of production and delivery of goods. Differentiation strategies have more to do with brand development, promotions, positioning of products in niche markets, customer satisfaction and being responsive towards customer needs and wants; hence it is no surprising that differentiation strategies are closely identified with marketing strategy of a business (Polanski, 2001).

Over the years marketing strategists have come to terms with environmental issues affecting the global community and some have thought of responding to these concerns as most of the environmental issues have to 
do with consumption. The term green marketing has begun to assume importance as result of firms finding ways and means of being receptive to environmental concerns. Green marketing basically refers to making sure that the marketing activities of a business are geared to be responsive to minimize environmental hazards. This shows an increasing recognition on the part of firms towards cementing a positive relationship with the customers who have shown alacrity for the preservation of environment (Crane, 2000).

Firms have recognized the value of green marketing as a step towards catering to customer needs while appreciating the significance to the growth and expansion of a business. It has become fashionable for companies to be touted being green as a way of identifying themselves with customers. Green marketing in fact represents a paradigm shift strategy in many business firms since it has altered the manner in which a business goes about in reaching out to the customers. Firms deploy number of green marketing strategies to outsmart rivals in the industry so as to gain competitive advantage. There are pitfalls and limitations in green marketing but overall as a marketing strategy it has brought about unique elements as strategy evolves in different contexts (Ottman, 1998).

\section{What is Green Marketing?}

As has been defined by many experts it can be concluded that green marketing refers to all marketing activities which are responsive towards protecting the environment. There is much avoidable confusion regarding the term green marketing, as people loosely identify it with various phenomena in the present era. Some attribute it as being responsive towards climate change and global warming, while others believe being in conformity with environmental standards as green marketing. Another group of people perceive recycling as inherent in green marketing while the majority of consumers and marketers alike simply identify green marketing as something that involves of promoting products emphasizing their contribution towards environment (Baker, 1999).

Since marketing is seen as a process whereby the marketing mix (Product price, promotions \& place) is used to respond to the needs and wants of customers while achieving business objectives many marketers have seen green marketing as simply another way of satisfying consumer needs under the same marketing mix. However a closer look at the concept of green marketing shows a distinct variation that has transformed the traditional marketing thinking (Kotler, 1997).

The term green marketing itself has undergone many changes with different terminology such as environmental Marketing and ecological Marketing being vaguely used. The word green marketing began to come to the surface in the 1980's since there was growing awareness of the global community regarding the environmental hazards and impending holocausts. It was in this context that environmentalists began to exert pressure on business firms to minimize the environmental pollution in the production of goods and services. The firms too have responded in equal measure by emphasizing and incorporating these environmental concerns in their business activities (Grant, 2007).

Today the concept of green marketing entails certain fundamental elements. Marketing products which are environmentally safe; developing and marketing products to minimize environmental hazards; produce, promote, and package products in a manner befitting so as to protect the environment are some characteristics of Green marketing as the term is understood in the present business world context (Ottman, 1998).

Green marketing involves establishing a link between the business and customer; and this process entails a holistic approach since business will naturally have to integrate all its activities in line with environmental concerns. As a strategy, green marketing involves strategic options such as Green products, Green packaging, Green prices and Green communication (Ottman, 1998).

Green products are recognized as ecologically friendly products. Green packaging which is the explicit phenomena in most instances has to do with suitable packaging that reduces environmental damage. Green prices show the reflection of environmental concerns in monetary terms which are intrinsic and transferable to the customer. Green communication fosters a positive image and coveys a business firm's concern towards the environment and the public (Ottman, 1998).

\section{Strategies of Green Marketing}

Change is inevitable in any sphere of discipline and marketing is no exception. The growing concern among consumers towards environment has forced business organizations to make changes in their marketing strategies. Green Marketing strategy encompasses two essential characteristics; Firms will have to take care in order to develop a product that would satisfy consumers' needs satisfactorily with minimum negative impact on environment; coupled with this is the creation of a perception in the minds of the customers so as to emphasize the quality of the product and the firm's commitment towards the environment (Menon et al., 1997). 
A green marketing strategy brings about a qualitative change in the relationship between customers and a business organization. When satisfying consumer needs using green marketing strategy, the functional as well as emotional benefits of a product will have to be highlighted since most environmental concerns involve spiritual needs of people. A green marketing strategy differs from a classical marketing strategy since it has more do with being proactive, Value based; long term oriented, integrated approach and more importantly the lives of human beings which are central to all initiatives (De Bakker \& Frank, 2009).

The proactive approach in Green marketing is aimed at gaining competitive advantage by strategically positioning the products in the minds of customers. The integrated business functions need to incorporate suppliers, distributors and business partners. All the key players down the business pipeline need to be made aware of green marketing objectives and this requires inculcating a sense of environmental consciousness among all the major players (Peattie, 1999).

In evolving a Green marketing strategy to derive competitive advantage a company has to do its own home work by being clear on what it ought to do. This aspect needs to be given thought since achieving organizational objectives would not simply result in profits; rather they involve making a positive contribution towards the environment. In order to reap advantage, a green marketing strategy has to address some fundamental areas of importance such as market segmentation, developing a green product, green positioning, setting green prices, application of green logistics, proper waste management, launch of green promotion, forging green partnerships and in essence having the right green marketing mix (Peattie, 1999).

A company in the first place has to select the customer group or the business activity which needs to be harnessed to reap benefits. Some companies prefer to indulge in promoting their products through proenvironmental media to reach out to environmentally conscious groups of customers (Staib, 2009). Most customers are concerned with the design of the product since many environmental hazards can be traced to the design part of the product. Hence it is incumbent upon a company to make necessary alterations in the product design to be in harmony with environment. This may require investing in new product development and seeking ways of introducing new designs in products. Having designed or developed products, they need to be positioned appropriately (Singh, 2004).

The pricing factor plays a major part of green marketing strategy since it is the monetary value paid by the customer. There is a tendency among customers to pay a premium price for green products considering the positive impact. On the other hand developing green products would have involved huge sum of money in terms of research and development, wastage management, recycling and incorporating other external costs. In the light of these facts some green products may have higher prices while some products would carry low process owing to the lowering of packaging cost (Keegan et al., 2000).

Another significant aspect of a green marketing strategy is the manner in which supply chain and the process of transforming inputs into outputs are handled. Care has to be exercised to have the environmental friendly production processes at the plant or factory by manufacturers. The proper handling of inventory may help to reduce waste and extraction of resources from the environment. In fact one of the major areas of growing concern has been the disposal of waste. A business has to avoid the release of waste in a hazardous manner to the environment. Business firms have begun to realize the importance of recycling of waste as an effective counterbalance to offset damages to the environment.

Effective green promotion is largely an outcome of selecting the right mode of means, channels and messages at the right time to reach out to the intended group of customers. One has to bear in mind that no promotion would be successful unless what is being propagated is not practiced at the business. In simple language this refers to walk the talk; that is doing what you say you will do. This is an area where the credibility of business is assessed by the customers. One of fundamental flaws that have backfired in green marketing strategies in the past is the absence of translation of words into deeds (De Bakker \& Frank, 2009).

Entering into strategic partnerships with other businesses in order to realize green marketing objectives has become a mainstay of companies. It can be observed that some business firms lack expertise or some may not have the requisite positive image to start off with a green marketing strategy. An ideal remedy would be to form alliances with business partners to further objectives. This would come handy if the partners have a proven track record of being environmentally conscious throughout. Such strategic partnerships would be mutually beneficial since there is a flow or exchange of knowledge and pooling of resources together (Zintom et al., 2001).

The proactive approach in green marketing has to recognize the value of continuous learning and adapting to the changing needs of customers. New technologies will have to be introduced and there should be new methods of using natural resources. A business firm using green marketing strategy will have to always explore and 
understand hitherto unexpressed desires and needs of the customers. These needs need to be aroused, catered to \& satisfied. In every effort towards gaining competitive advantage a business has to be aware of the need to be in compliance with ecological standards (Pickett et al., 1997).

\section{Marketing Mix in Green Marketing}

Marketing mix refers to generally the different ways made use of by a company to bring a good or service to the market. In green marketing, the marketing mix will have to be responsive towards environmental concerns. In the case of service sector products marketing mix is known as the extended marketing mix. Marketing mix as popularly known as 4P's comprises of components such as product, price, place and promotion. In the extended marketing mix as in case of service products people, physical evidence and process are added to make up 7P's. As per green marketing philosophy each element in the marketing mix must have a green outlook from developing to introducing a product to the market (Kotler, 1997).

A product could be termed as a green product if the process of production is ecofriendly and causes less damage to the environment. A business has to minimize the environmental pollution in its production process. The raw materials contained in a product should be extracted in manner so as to preserve natural resources. Waste management as has been discussed forms a vital area in this connection. Business will have to introduce ecofriendly design and the packaging should minimize pollution and hazards. Product improvements necessarily involve considerable sunk costs but they are worth the effort since changes in the product would bring about a turnaround in sales. The technique of reversed logistics whereby customers return to the business used packaging, wrapping and even the used product itself would considerably help to preserve the environment (Peattie, 1999).

Going green is expensive as they involve numerous costs such as installation of new technology, machines, training people, absorbing external costs, converting waste in to recycled products. Obviously these costs would make into the price of a product. Hence green price is a premium price. There is added burden on promotions due to premium price. Marketing efforts will have to justify these expenses \& consumers need to be persuaded to pay a premium. All this would require rational messages in adverts. However the price of green products may be low in case of doing away with packaging material. In fact some businesses have found this to be an attractive proposition when packaging costs form a large part of the unit cost (Peattie, 1999).

Green distribution involves selecting channels in a manner so at to minimize environmental damages. Mostly damages to the environment are caused during transportation of goods. Hence safety precautions will have to be introduced in the delivery of goods (Peattie, 1999).

Green marketing has to go into the promotional material of a business. The key message of being green has to be conveyed to the customers through sales promotions, direct marketing, public relations and advertising. Public relations and advertising in fact have become the most widely used platforms to project the green outlook of a business. Going green sometimes turns out to be a major public relations exercise as it builds a bridge between the business and the community. Green advertising can be used to publicize products, justify their features and price (Peattie, 1999).

Green promotional strategy should realize the fact that most customers are not truly aware of the significance of green product since lack information. To address this void in the absence of information a business can resort various green promotional strategies. Customers need to be informed of the types of environmental problems a product would solve in the first place for them to evince an interest in a green product. More over customers need to be shown a range of solutions that can be made use in order to protect the environment. Customers need to be given assurance of the performance of green products as to their efficacy since some have doubts over the functioning of so called green products (Peattie, 1999).

Consumers who prefer green products would be more receptive to direct marketing channels. Public relations can be projected as a means of building a positive image about the organization as a whole. Green marketing has to focus on identifying needs and directing consumers to use less harmful products to the environment. Hence green marketing strategy has to be supported by marketing research (Gottfried, 2004).

A company adopting green marketing as a business strategy will have to make some adjustments in their internal process. This requires restructuring of the business process. It is a misplaced belief to assume that only the marketing division in an organization can bring about a turnaround through green marketing. Green marketing in fact will have to be a green strategy by aligning the other functions in the organization. This implies that in order to gain competitive advantage a business has to make changes in the philosophy of the company. There has to be strategic fit by aligning the marketing strategy with the business strategy (Grant, 2007).

A change in business model as required by green marketing can be achieved through contemplating certain 
measures. An environmental audit needs to be undertaken to establish standards and measure the current performance in terms of impact on the environment. A green strategy would be aided if the management of a business goes beyond what is generally accepted as green marketing. The keenness of the management has to be demonstrated. Employees need to be encouraged throughout to make positive contributions by conducting educational programmes. The positive performance results will have to be periodically published to enlighten stake holders of a business. There has to be integration the products and process though continuous learning (Menon et al., 1997).

Marketers can resort to a life cycle analysis of products whereby various positive and negative contributions by a product it in different stages of its life cycle can be listed. This analysis would through light on harmful effects at the stages of processing, packaging, transporting and selling of products (Menon et al., 1997).

It is no exaggeration that environmental issues cannot be simply solved by businesses alone. This effort requires the combined support of various stakeholders. This is where strategic partnerships come into play. Strategic partnerships often involve joining hands together with general public, suppliers, employees, regulators, pressure groups, competitors (Grant, 2007).

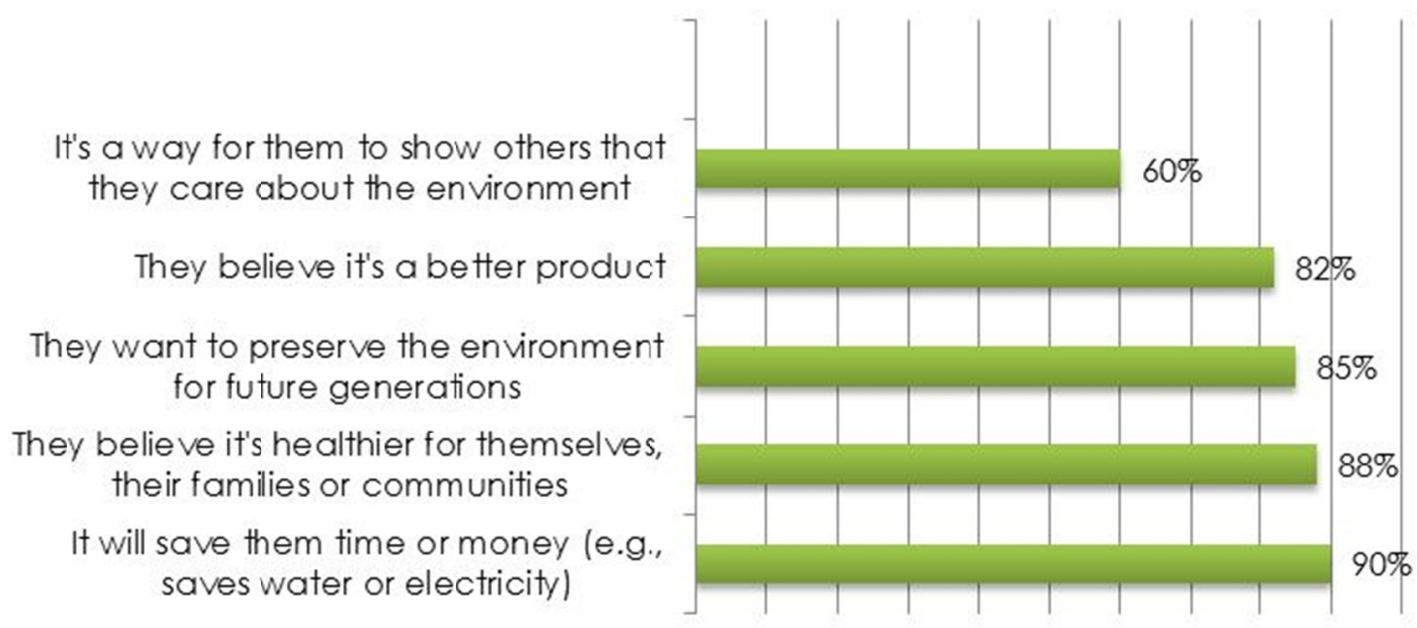

Figure 1. Why Americans are motivated to purchase environmental products

Source: Extracted from: www.snappygreen.com

The above diagram shows the motivation for Americans to purchase green products.

\section{The Effectiveness of Green Marketing as a Business Strategy}

A green marketing strategy brings about certain benefits to a business which can be harnessed to derive competitive advantage. One of the main benefits has been the reduction in cost of production. Green production process would result in cutting down costs in terms of less waste, less use of raw materials and saving of energy costs. A significant reduction in cost would raise the profits of a business (Baker, 1999).

Another advantage that accrues to a business as a result of green marketing would be the brand loyalty. Studies have proved that customers attach less importance to brand loyalty in the case of products which carry intrinsic benefits. Green products are held in a different perspective owing to their contribution to the environment. There develops a spiritual relationship between green products and customers. Increased brand loyalty would make a product less price sensitive so that even if the product carries a premium still customers would tend to buy them. Even in times of economic downturns green products would witness a less drop in sales since owing to health concerns even at worst times consumers look for a positive outcome (Baker, 1999).

Green products would foster a positive image about brands and the business as a whole. Being green may increase customer attraction and the company may gain recognition among the populace at large. Even consumers who do not use products of a company may switch their allegiance. Green product companies would be able to gain acceptance from regulators and the general public so that many promotional activities would bear fruit without much effort since the general public at large would respond to them enthusiastically. The positioning of product in the mind would occupy a strategic position so that most green products would become 
top of the mind products as they can be easily recalled by customers. This would serve as a unique selling proposition so that a business stands out among rival firms quite easily (Baker, 1999).

Producing or selling of green products would result in a pleasant business environment with reduction in chaotic business activities. This would enhance the ambience and healthy working environment. Since the process of evolving a green marketing involves a holistic approach aligning all the functions of the business a strategic congruence can be attained. Apart from this, the strategy formulation would build better relationships with employees as their participation is sought. Employee engagement would increase and there would be a mutual understanding between different stakeholders of a business (Zintom et al., 2001).

A business would stand to gain mileage if it introduces an innovative ecological product to the market as customers can be lured from existing products in the market. A green marketing strategy would result in a win-win situation for business stakeholders as in the process there would be pooling together of each other's skills, capabilities and resources which are transferred. In the end consumer satisfaction increases since customers would be able to get high quality products at reasonable prices. This would increase the overall welfare of an economy and a sustainable development would result from green marketing initiatives (Baker, 1999).

\section{Limitations of Green Marketing as a Strategy}

Green marketing as a business strategy came to entice businesses in the early part of the 1980's as the evidence suggest that there was a growing concern among consumers to consuming green products. Corporate sector began to respond to this concern by making green products $\&$ green practices as fundamental to their business processes. In fact at the beginning of the 1990's many companies that successfully ventured into green marketing stood to gain over their rival firms. It can be observed that at the height of green marketing there was a plethora of corporate activities and academic interest in the subject as if frenzy was on (Smith, 1998).

However beginning from the latter part of the 1990's green marketing began to lose much of the euphoria surrounding it owing to various reasons. It is pertinent to understand these reasons as they provide a clue as to the limitations of green marketing strategy as a means of gaining competitive advantage (Menon et al., 1997).

One of the drawbacks of green marketing strategy lies in the difference between the concern for the environment and translating this concern into actual purchase decisions. Most of the market research carried out would bear testimony to the fact that consumers prefer environment products and they indeed value preserving environment. But the purchase decisions of customers would not be solely governed by their concern for the environment. This is a complex phenomena associated with consumer behavior (Menon et al., 1997).

It cannot be denied that the products in the mainstream markets over the years have improved their quality and reduced the impact on environment. In the light of this green products may no longer appear to be superior or preferred by customers. Fundamental to this problem is the growing cynicism with which green products are perceived by customers. Since there has been a polarization of the market with claims of being green, customers have begun to doubt the authenticity of such claims. Lack of trust serves as a major impediment to stimulate purchasing decisions of customers. Some green products are no longer unique since as customers believe that the industry itself has become green. Too much emphasis on green has made the customers aver the preference for them as generic (Smith, 1998).

Green marketing strategy sometimes would be constrained by the finance orientation in marketing. There can be a tendency in a business to embrace green marketing solely as a cost cutting measure since reducing packaging can be touted as a response towards being green. In fact a finance orientation would create short termism and a business may be greedy in its green activities. Instead of developing new products business may be bogged down by cost cutting. Green marketing suffers from compartmentalization since green marketing strategy is confined to the marketing division and there is little effort if no effort at all in integrating it with the business strategy. As a result green marketing becomes an isolated activity with less input from other business functions. In such a scenario the strategy may never help the company to gain advantage (Smith, 1998).

Many business firms have come under criticism for resorting to green marketing since they are perceived to be engaged in a green spinning. Some critics would argue that a business that has been at the end of criticism for damaging the environment may suddenly turn green or propagate being green as a diversionary tactic. Hence a green strategy may be seen as eyewash and subjected to ridicule by pressure groups and media let alone other rivals in the industry (Singh, 2004).

Public relations exercises carried out under green marketing may turn out to be cosmetic steps unless they are supported by the business activities and practices. If a business cannot control the harmful effects of its suppliers 
and other business partners then green marketing would turn out to be lacking overall control (Peattie, 1999).

Green selling is another phenomena encountered by marketers when implementing a green strategy. A business may be prone to adopt a complacent attitude believing that anything green would sell and must sell. Business may attempt to solely focus on promotional activities without resorting to product development. Customers may not see a difference between the actual product $\&$ the claims made through adverts. Business firm implementing a green strategy may be hindered by compliance marketing whereby immediate concern would be to merely comply with the environmental regulations laid down by regulators. This approach may not encourage a firm to go beyond the average standards and a business cannot be distinguished from other businesses in such a scenario (Smith, 1998).

A green strategy may create confusions in the minds of customers as to the types of decisions to be made. As the market is flooded with numerous green products customers may be at loss in making choices. This is especially true in the case of recyclable products. Many customers are unaware of the manner in which to deal with recycling process (Menon et al., 1997).

Green strategies in general and green marketing strategies in particular are costly and they require long term planning. The outcome of a green marketing strategy cannot be expected in the short run. Most of the benefits of green marketing are not directly related to consumer decision making since they may not clearly identify them. Apart from this environmental benefits cannot measured so easily and they cannot be directly attributed to a marketing strategy (Menon et al., 1997).

The success of a green marketing strategy is largely dependent on the contribution made by different stake holders of a business and different functional divisions of a business. The top management commitment towards a green market strategy would be crucial since in many instances green strategies have failed to deliver the goods owing to the internal dynamics with in the organizations. To overcome these difficulties, a business has to look at the concept of green marketing in an innovative way to reap the benefits. It has to be conceded that green marketing alone would no help a firm to gain competitive advantage in the present business context (Baker, 1999).

\section{Conclusion}

Competitive advantage gives a business firm superiority over its rivals so that it can earn profits consistently. Business firms use diverse strategies to gain competitive advantage over rivals ranging from low cost, differentiation, focus strategy etc... The type of strategy to be used in the business world has aroused much interest and it can be surmised the strategy too is responsive towards the consumer needs.

Over the years marketing strategists have come to terms with environmental issues affecting the global community and some have thought of responding to these concerns as most of the environmental issues have to do with consumption. Green marketing has begun to assume importance as result of firms finding ways and means of being receptive to environmental concerns. Firms have recognized the value of green marketing as a step towards catering to customer needs while appreciating the significance to the growth and expansion of a business.

As the term is understood at present, the concept of green marketing entails certain characteristic such as marketing products which are environmentally safe; developing and marketing products to minimize environmental hazards; produce, promote, and package products in a manner befitting so as to protect the environment. Green marketing involves establishing a link between the business and customer. A green marketing strategy brings about a qualitative change in the relationship between customers and a business organization. The proactive approach in Green marketing is aimed at gaining competitive advantage by strategically positioning the products in the minds of customers.

In order to gain competitive advantage, a green marketing strategy has to address some fundamental areas of importance such as market segmentation, developing a green product, green positioning, setting green prices, application of green logistics, proper waste management, launch of green promotion, forging green partnerships and in essence having the right green marketing mix. In green marketing, the marketing mix will have to be responsive towards environmental concerns.

A green marketing strategy brings about certain benefits to a business which can be harnessed to derive competitive advantage. These benefits would accrue to a business in the form of reduction in cost of production, fostering a positive image about brands and the business as a whole, positioning of product in the mind of customer would make it a top of the mind recall product. Consumer satisfaction increases since customers would be able to get high quality products at reasonable prices thereby increasing economic welfare of the society. 
Since there has been a polarization of the market with claims of being green, customers have begun to doubt the authenticity of such claims. A green marketing strategy may be vulnerable to finance orientation, growing cynicism, green spinning, and green selling. The success of a green marketing strategy is largely dependent on the contribution made by different stake holders of a business and different functional divisions of a business.

\section{References}

Crane, A. (2000). Facing the backlash: green marketing and strategic reorientation in the 1990s. Journal of Strategic Marketing, 8(3), 277-296. http://doi:10.1080/09652540050110011

Davies, R. (2007). Why John Grant has helped make sense of the green debate. GREEN Marketing Manifesto, 47.

De Bakker, \& Frank, G. A. (2009). Corporate Culture and Environmental Practice: Making Change at a High-Technology Manufacturer. Organization \& Environment, 22(2). http://doi:10.1177/1086026609338170

Gottfried, D. (2004). Greed to Green: The Transformation of an Industry and a Life / What Matters Most: How a Small Group of Pioneers Is Teaching Social Responsibility to Big Business, and Why Big Business Is Listening. Booklist, 100(9).

Keegan, W. J., \& Green, M. S. (2000). Global marketing (2nd ed.). Englewood Cliffs, NJ: Prentice-Hall.

Kotler, P. (1991). Marketing Management: Analysis, Planning, Implementation and Control. Journal of Marketing Management, 7(4), 426-427.

Mayer, R. N., \& Iyer, E. (2000). Greener Marketing: A Global Perspective on Greening Marketing Practice. Journal of Public Policy \& Marketing, 19(1), 151-152. http://dx.doi.org/10.1509/jppm.19.1.151.16943

Menon, A., \& Menon, A. (1997). Enviropreneurial Marketing Strategy: The Emergence of Corporate Environmentalism as Market Strategy. Journal of Marketing, 61(1), 51-67. http://dx.doi.org/10.2307/1252189

Meredith, B. H. (2002). One more time—-what is marketing? NZ Business, 16(9).

Ottman, J., \& Miller, D. S. (1999). Green Marketing. Electronic Green Journal.

Peattie, K. (1999). Shifting to a Greener Paradigm. In Charter, M., \& Polonsky, M. (Eds.), Greener marketing, A Global Perspective on Greening Marketing practice. Greenleaf Publishing.

Pickett, M., Kangun, N., \& Grove, J. (1995). An examination of the conserving consumer: Implications for public policy formation in promoting conservation behavior. Environmental marketing Strategies, practice, theory and research. Haworth Press.

Polonsky, M. J., \& Rosenberger III, P. J. (2000). Re-evaluating Green Marketing-A Sophisticated Strategic Marketing Approach. AMA Winter Educators' Conference Proceedings, 11.

Porter, M. E., \& Van der Linde, C. (1995). Green and Competitive: Ending the Stalemate. Harvard Business Review, 73(5), 120-134.

Staib, R. (2009). Business management and environmental stewardship: environmental thinking as a prelude to management action. Palgrave Macmillan.

Singh, S. (2004). Market Orientation, Corporate Culture and Business Performance. Ashgate Publishing.

Smith, T. M. (1999). The Myth of Green Marketing: Tending Our Goats at the Edge of Apocalypse. American Journal of Sociology, 105(1).

Zintom, M., \& Frederick R. (2001). Marketing and advertising, A Deep Green Company. The Journal of Corporate Citizenship.

\section{Copyrights}

Copyright for this article is retained by the author(s), with first publication rights granted to the journal.

This is an open-access article distributed under the terms and conditions of the Creative Commons Attribution license (http://creativecommons.org/licenses/by/3.0/). 